\title{
Les Tricoteuses: The plain and purl of solidarity and protest
}

\author{
Liz Stops
}

\begin{abstract}
This paper focuses on the use of knitting as a protest tool by the Knitting Nannas Against Gas (KNAG), a group formed to combat the development of Unconventional Gas Mining (UGM) in the Northern Rivers of New South Wales. KNAG is socially and politically motivated, but not aligned to any political party. The group's 'Nannafesto' emphasises care for community and country while protesting against corporate greed. I situate KNAG within a broad historical and contemporary framework of similarly motivated movements that have used knitting as a tool for social, cultural and ideological influence. I also elaborate on the act of knitting as a form of witness bearing, a means to facilitate calm persistence, a strategy for processing ideas and an instrument for reinforcing the threads connecting community.
\end{abstract}

In this paper I outline investigations into knitting as a tool for social and political action, as demonstrated by the activities of the Knitting Nannas Against Gas (KNAG). KNAG is a loosely structured organisation that was established in Lismore in the Northern Rivers district of New South Wales in June 2012 by longterm residents Clare Twomey and Lindy Scott. Twomey, an artist and parent, and Scott, a childcare worker and grandparent, turned their organisational and creative skills to initiating KNAG as a tool for effective protest against Unconventional Gas Mining (UGM). UGM encompasses a number of mining opportunities that are present in the geology of northern New South Wales, with coal seam gas (CSG) being the most commonly known.

KNAG engages in a variety of activities, for instance, knit-ins at government offices; knitting objects that reinforce, nurture or protest; farm gate protests; rallies; and blockades. Here, I dwell particularly on the KNAG potential for community nurture and the role the group plays in political subversion and disruption. This discussion is placed in the broader context of historical and contemporary politically motivated craft actions.

As a member of KNAG I have shared many knit-ins and participated with KNAG and hundreds of others in gas mining blockades since late 2012. I am also involved with groups endeavouring, through non-violent direct action (NVDA), to prevent gas exploration and production companies drilling exploration wells in my local area, the Northern Rivers of New South Wales. One company in particular, Metgasco, holds widespread gas exploration licences and a limited CSG production licence for this region. In response to community action, Metgasco withdrew from exploratory activities here in March 2013, having been active in the area to varying degrees for over ten years. Months later, though, 
the company expressed its intention to return and, in February 2014, the NSW state government approved its application to drill an exploration well at Bentley, seven kilometres from my home.

KNAG is socially and politically motivated, but not aligned to any political party. The group is closely affiliated with the Lock the Gate (LTG) Alliance, whose members seek to prevent massive industrialisation of the rural landscape of the Northern Rivers by UGM ventures. A close connection with the LTG Alliance is referenced through KNAG's use of the LTG Alliance logo of a yellow triangle superimposed with black text. This is used on banners at knit-ins and on a variety of knitted objects. Local property owners wanting to make clear their affiliations have attached LTG Alliance triangles to entrance gates, fences or trees on the perimeters of their land.

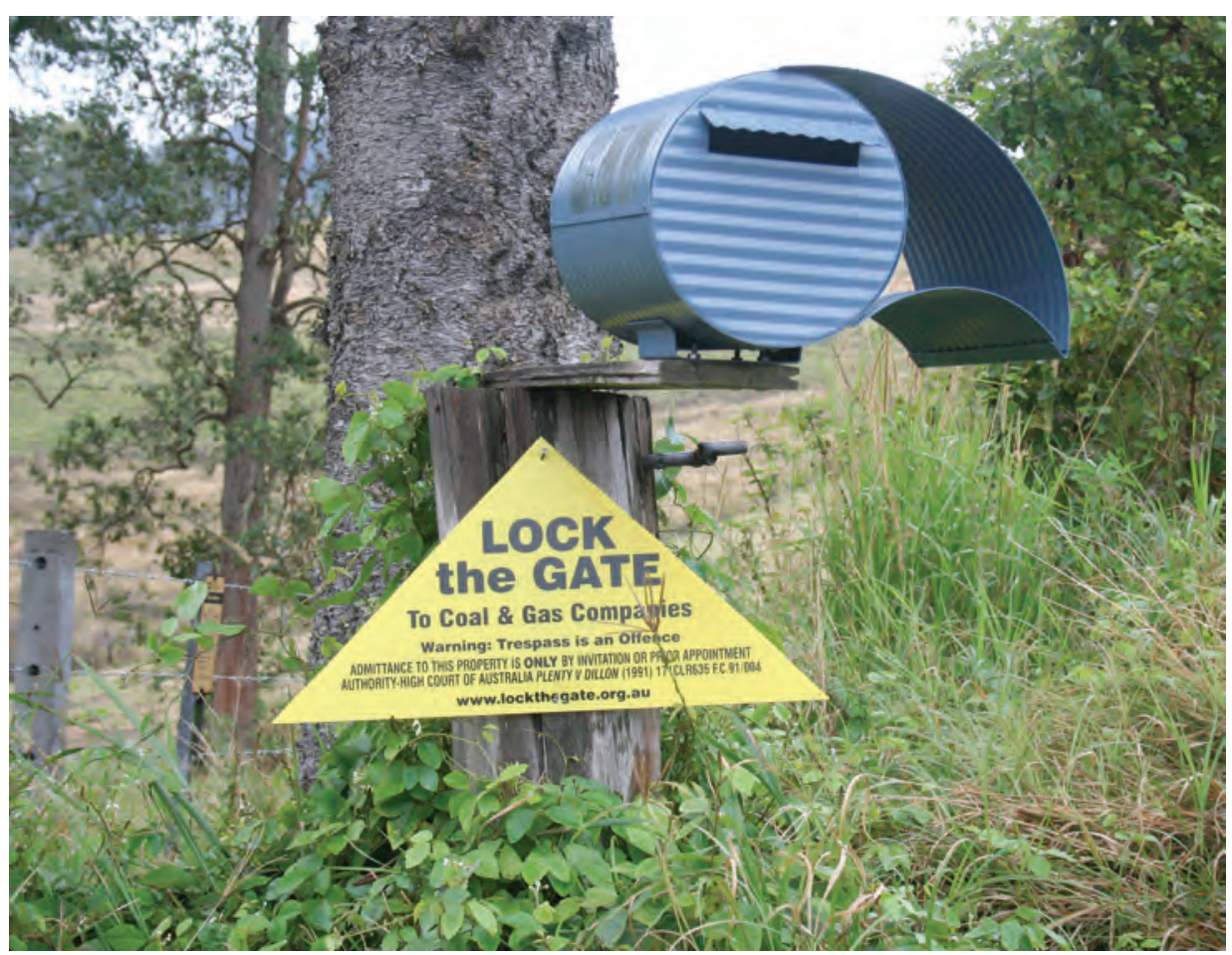

Figure 1. Lock the Gate Alliance triangle secured to property entrance

Photo: Liz Stops 2013

The term 'Les Tricoteuses' commonly refers to women who sat knitting at the base of the guillotine in silent protest at their enforced exclusion from political participation during the Reign of Terror during the French Revolution. According to Henry Stephens, in 1789 market women marched to Versailles as heroines (1891: 358-59). They received medals and were encouraged to hound the aristocracy, 'playing an important part in the street history of Paris ...' (Stephens 1891: 358). In 1793, however, they were excluded by decree and deprived of 
active participation in political assembly. They then became more widely known as Les Tricoteuses, or knitting women, sitting in the Place de la Revolution, watching the guillotine as they knitted, having lost any active power for good or harm. Although they were perceived as callous, Ann Galloway suggests that they could have been 'handling stress by handling objects' (2006).

KNAG members have observed a similar marginalisation of ordinary voters in the present day, whose voices have been stifled by politicians under the sway of powerful corporations. Beverly Gordon's view is that 'textile-making is an important form of speech' through which women can be empowered and find their voices (2011: 211). Knitting serves that purpose for KNAG members, who feel they are unrepresented by politicians. In the same way that Les Tricoteuses took their craft to the streets, KNAG has also rendered the domestic public. Galloway questions why knitting in public can be unsettling and whether it is due to the intrusion of an activity that is usually considered private into a public space, or perhaps the fear that those knitting will not want to engage with those around them:

A woman knitting in public is self-possessed, she almost flaunts her ability to be productive when others can't, to create when others can only consume. From this emotional politics she can also claim moral righteousness, and in the multi-tasking dimension, she can claim superior skill and challenge the notion that public space is unitary or unified in process and product. (2006)

As well as being a reminder of Les Tricoteuses, knitting as a tool for protest is linked to other historical connections with craft activism. In 1908 the British women's suffrage movement, drawing on the banner-carrying tradition established by the trades union movement from the 1830s, demonstrated for their cause carrying finely embroidered pennants (Parker 1996: 197-98). Suffragette banners were uniquely devised and well finished, combining embroidery, paint and collage. They were intended to evoke 'femininity represented as a source of strength, not as evidence of women's weakness' (Parker 1996: 197). Gordon proposes that '(i)f threads serve as connectors that literally and figuratively tie things or people to one another, then intertwined filaments are particularly potent images, as they are strong and durable' (2011: 25). Similarly, the women who participate in KNAG initiatives seek to highlight enduring strength and a determination to be heard. One way they demonstrate such determination is through persistent lobbying via knit-ins outside the offices of state and federal politicians, often accompanied by applications for an audience or letters stating concerns.

An inspiring example of persistence and enduring strength in women's activism is portrayed in the 2008 documentary Pray the Devil Back to Hell, directed by Gini Reticker, which tells the story of Leymah Gbowee who challenged the Liberian dictator Charles Taylor in 2003, bringing together Christian and Muslim women in a non-violent movement against Liberia's civil war (Fork Films 2008). Gbowee helped organise, and then lead, the Women of Liberia Mass Action for 
Peace. She emerged as an international leader who changed history, marking the vanguard of a new wave of women taking control of their political destiny around the world (Gbowee \& Mithers 2013).

The Nannafesto, which can be found on the KNAG website, emphasises care for community and country while protesting against corporate greed. The group operates autonomously, but in consultation with the LTG Alliance and other similarly concerned organisations. All KNAG members engage in NVDA training before participating in any activity that has the potential for confrontation, such as blockading properties against drill rigs. Police, UGM workers and landholders are all treated with respect while implacable determination to prevent environmental destruction and community division is retained, the catchcry being, 'non violent but non negotiable'.

The name, Knitting Nannas Against Gas, was purposefully devised. 'Knitting' and 'Nannas' are words that immediately conjure a nostalgic image of older women exuding trust and love. Nostalgia 'has come to connote a yearning for some real or imagined time and place in the past that is suffused in sentiment and purged of pain' (McCalman 2006: 73). It might also form a 'collective search for identity' (Davis 1979: 107-08) when societal norms shift and previous certainties dissipate, as happens when people discover that their rights have been eroded. Crafts, such as knitting, can also be thought of as 'vehicles for nostalgia' (Pocius 1994: 127) because of their long historical lineage. The acronym KNAG, with its silent $\mathrm{K}$ when verbalised, injects humour into perceptions of the group and affirms the persistence and determination of its members.

Strands of wool passing through hands to needles during knit-ins serve as reminders that threads are 'a component of many human stories across different cultures' (Gordon 2011: 23) Theseus, for example, trailing a thread to mark his pathway back to Ariadne, after slaying the Minotaur; the prince in the Brothers Grimm fairytale The Spindle, the Shuttle and the Needle following a magic spindle to find his bride; and the thread that, according to Hindu scriptures, links worlds and beings (Gordon 2011: 23). Kate Darian-Smith suggests, in relation to the warp and weft of the loom, that the two elements together establish history while affirming memory and the purl and plain of knitting might be similarly regarded (Hamilton 1994). KNAG's craft-based protests build an archive for the future while drawing on collective knowledge of the past. In this way memory and history 'nourish each other' (Hamilton 1994: 13) as participants build a strong sense of group identity.

Knitting can also facilitate thought processes that lead to effective strategy development. According to Claire Pajaczkowska, '(o)ne of the most misguided conceptions of epistemology that arose from the anxiety of monotheisms, and their cultures is the belief that thought emerges from inactivity' and she argues that 'thinking arises through making' (2005: 243). She also suggests that 'thinking is first, and foremost, a fabrication' and the 'impact ... of bodily 
awareness of movement is represented through an image of vitality' (2005: 243). Galloway expresses the view that 'knitters can sometimes enter a fluid state of thinking that is superior to (the) usual clunky, solid state of mind' (2006).

Knitting takes place at meetings and at actions. In meetings knitters are always busy, and at actions, for instance when maintaining vigils to detect machinery movement at exploration sites and company depots, a ball of wool and needles are always at hand. It is a means to an end, however, not an end in itself. KNAG's founders saw knitting as a means of taking purposeful action towards social and political change by tenaciously bearing witness to mining activities: they believed that knitting could serve as a vehicle in this process. Twomey, however, continues to emphasise that 'it's not about the technical excellence of the knitted object' (2013). Andrea Black and Nicole Burisch also note 'the radical potential of a particular craft activity rather than its finished end-product', shifting emphasis away from a polished object towards a political and conceptual focus (2010: 610).

Gerald Pocius considers how the nature of craft may have changed when objects become the symbol for social issues and are less important than what they represent (1994: 129-30). He also questions why 'crafts become a symbol of a group', concluding that 'we make something and somehow connect ourselves' and that 'craft is no longer primarily that which is useful or pleasing but objects that settle our uneasiness about who we are' (1994: 129-30). Art historian and initiator of the Viral Knitting Project (VKP), Kirsty Robertson, refers to knitting as 'a sophisticated technological metaphor for networks of connection outside of and against the globalization of capital' (Pentney 2008).

The VKP was a collaborative endeavour to combine the links between computing and knitting with an activist agenda of questioning increased surveillance and the tightening of security after 9/11 (Robertson n.d.). As Beth Ann Pentney proposes, knitting 'can be readily politicized for different purposes by different groups and individuals' (2008). KNAG members have observed and discussed how, through knitting, networks have been formed and used for activist goals by people who may not usually identify as activists, or even knitters. Rather, they are people who have been denied a voice and are seeking to address that situation. Twomey and Scott exemplify this in that they have no prior experience of political activism and are not adept knitters.

Gordon, referring to cloth, argues that the '(i)mages of entwinement ... the idea that we are all threads entangled together ... symbolise the idea the whole is much more than the sum of its parts' (2011: 25). Knitting can be viewed in the same way, the VKP being cited as collaborative and interactive (Robertson n.d.). KNAG operates similarly. The group is composed of a floating pool of participants who are mostly older women. As a consequence, it is possible to draw upon a vast range of life experience and skills. Many KNAG members are old enough to have retired from paid employment, are usually child free and, although leading busy lives, may be more able to commit to the sometimes gruelling KNAG timetable than younger women whose participation may be 
enthusiastic, but is always fleeting due to family and work commitments. Men of varying ages often attend knitting actions though, to date, none have taken up needles.

Pajaczkowska, drawing on the work of Levi Strauss, discusses weaving in terms of "transforming the "raw" material of nature into the "cooked" language of culture ... animal hair or vegetable fiber is transformed into a medium for human relationship' (2005: 233). Knitting can perform the same function. For instance, the VKP sought to 'incorporate knitting as protest into knitting as communication' (Robertson n.d.). Similarly, in maintaining vigilance, KNAG uses both the act of knitting and the objects knitted to calmly and peacefully communicate persistence, diligence, solidarity and determination.

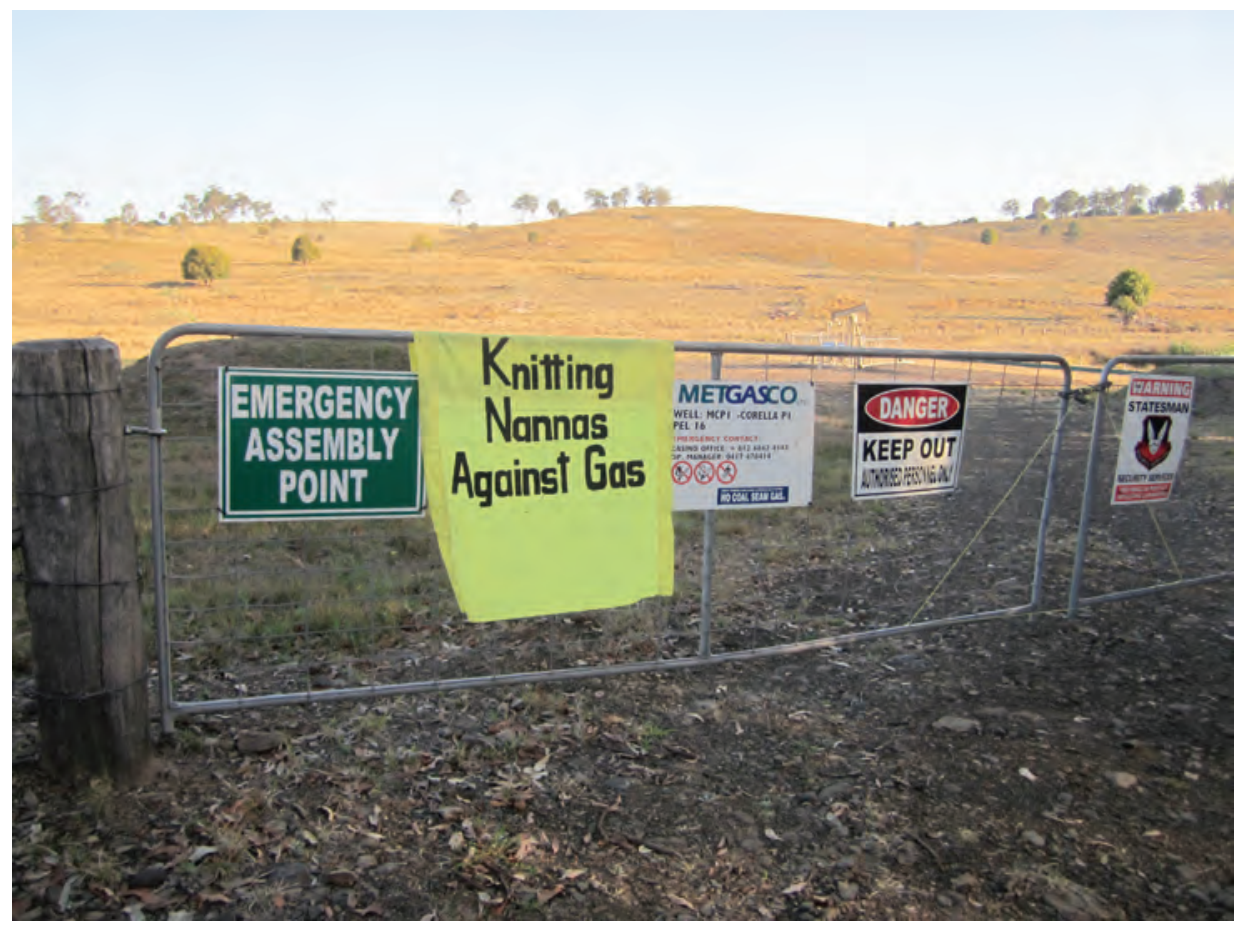

Figure 2. KNAG banner on Metgasco fence

Photo: Clare Twomey 2012

Providing information is a strong component of the group's Nannafesto and motivates many KNAG actions. Between June 2012 and January 2013 Nannas regularly conducted tours of known exploration well sites and equipment depots in the Northern Rivers. Each tour functioned as an introduction to the impact of UGM exploration for those who were not familiar with the industry. Importantly, tours served also as an opportunity for bearing witness: changes at the sites were photographed to document such things as a decrease in stored equipment at depots, or an increase in vehicle traffic at a well site. Such 
indications of increased activity were useful as an alert for follow-up actions. On tours, a photograph was taken of the KNAG banner draped alongside mining company signs; these images were archived on Facebook.

An artifact was always left behind during these excursions as a reminder that company undertakings were consistently observed and recorded. Usually this would take the form of a yellow yarn triangle that echoed the LTG Alliance version, arranged as if to prevent workers opening the depot or well-site entrance.

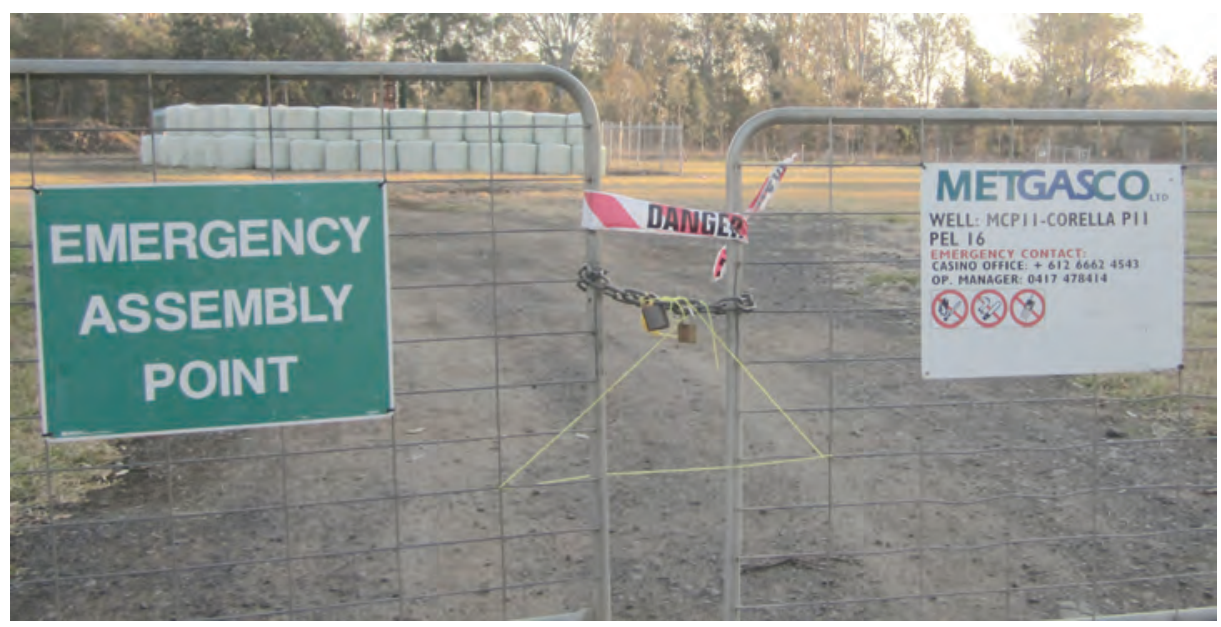

Figure 3. Yellow yarn triangle on Metgasco gate

Photo: Clare Twomey 2012

This kind of soft barrier is a deliberate tactic that is often deployed by KNAG members. Although in reality the yarn is easily detached, its presence sends a strong message of vigilance to workers who may visit the sites, as well as to their management. It is a strategy also deemed significant by the Revolutionary Knitting Circle (RKC), a Canadian group most politically active in 2007. According to Pentney, soft barriers 'are symbolic of local alliance and represent the rejection of economic progress in the form of corporate wealth ... at the expense of local producers and citizens' (2008).

Extended soft barriers have assumed huge importance at blockades. As well as using tied strands of yarn to symbolically secure gates, Twomey and others have knitted soft barriers many metres long, some of which are thrown across gates and roads that are in imminent danger of invasion by drill rigs. The following image details such an event at Glenugie in December 2012, where Metgasco was attempting to import equipment to drill an exploration well. This blockade was successful and the drill invasion was delayed for seven weeks. 


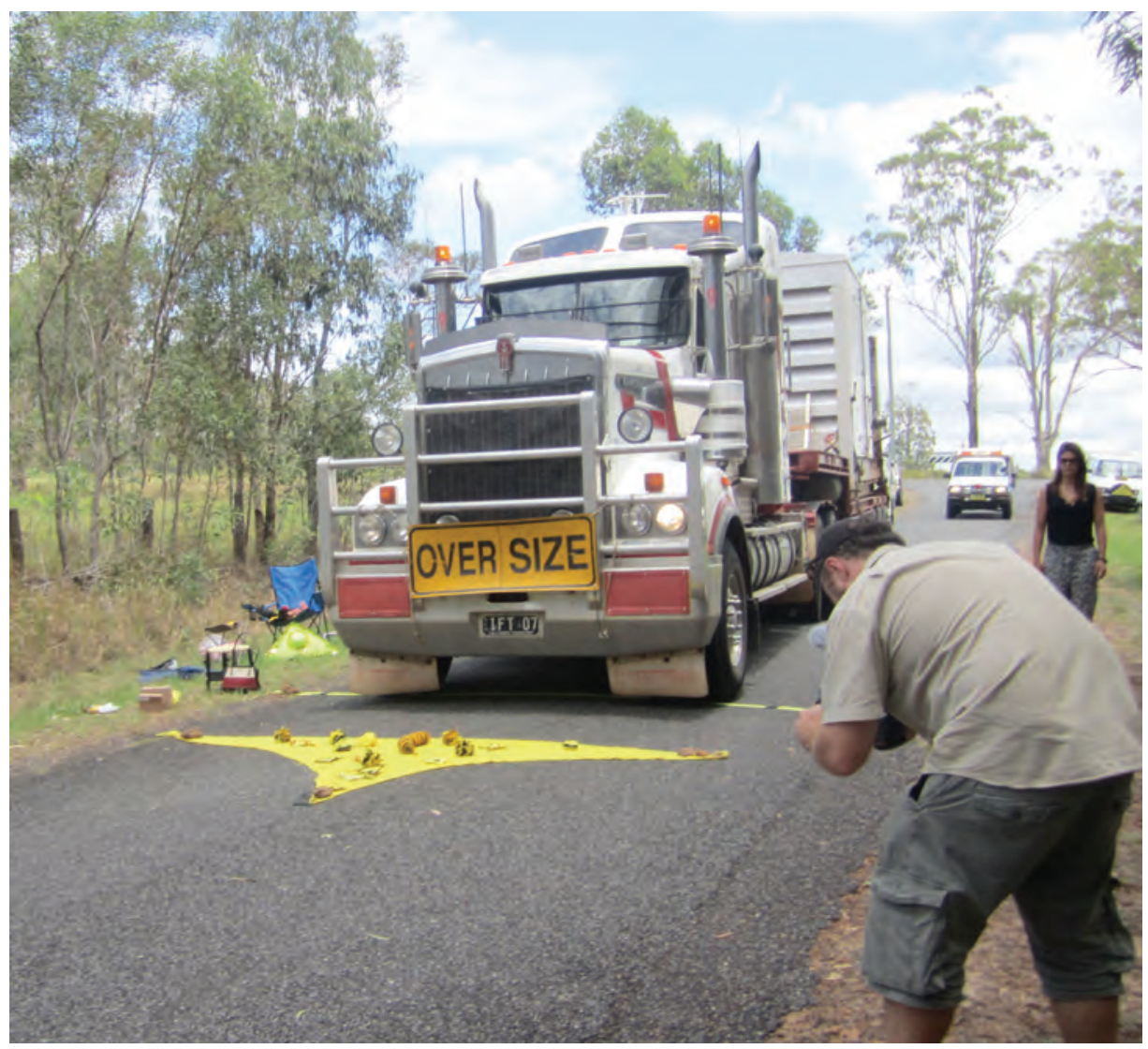

Figure 4. Metgasco truck with heavy equipment running over soft barriers

Photo: Clare Twomey 2012

The same barrier, having grown considerably longer through a succession of knit-ins, was draped on a tripod installed over an entrance gate to a projected drill site at Doubtful Creek in February 2013. Here, Twomey sat atop the tripod knitting and filming while 300 blockaders below her attempted to prevent the passage of a truck bearing a drill rig. Charged by police, but subsequently acquitted, her tripod, including the knitted length, was bulldozed once police had cleared the area of people. Twomey's torn and muddy knitting, however, was rescued from the bulldozed pile and now acts as a 'memory cloth' (Gordon 2011: 212), a marker and reminder of a significant event. Describing how a 'tear or rent in the social fabric' can be 'a tactile metaphor for a collective trauma or destruction'. Pajaczkowska notes also the 'reparative functions of darning, patching and mending' (2005: 240). Twomey, however, seeing no reparation, has resolved to leave the knitted length unmended until mining companies leave the area and the social fabric is restored. 
Les Tricoteuses: The plain and purl of solidarity and protest

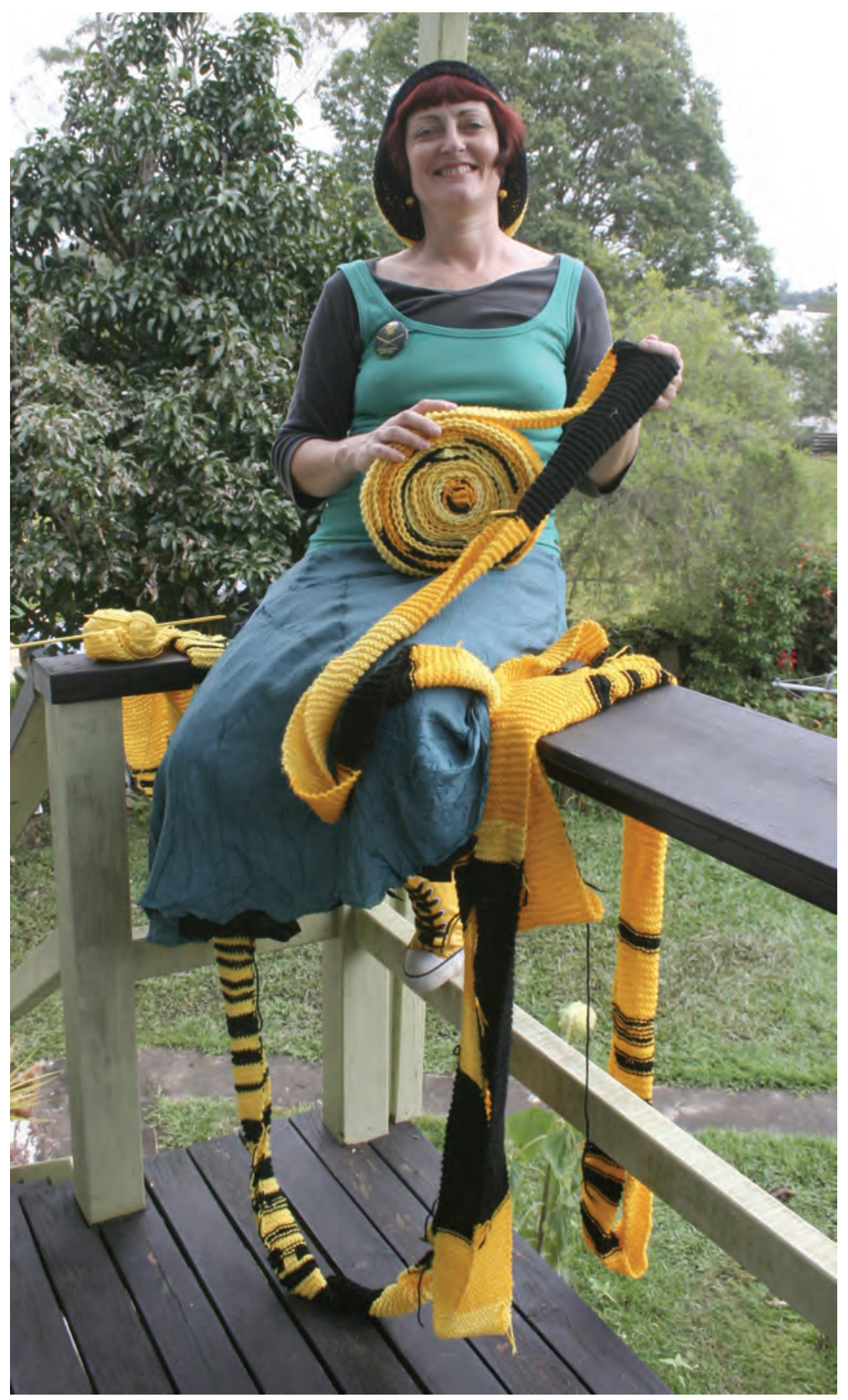

Figure 5. Clare Twomey with soft barrier

Photo: Liz Stops 2013 


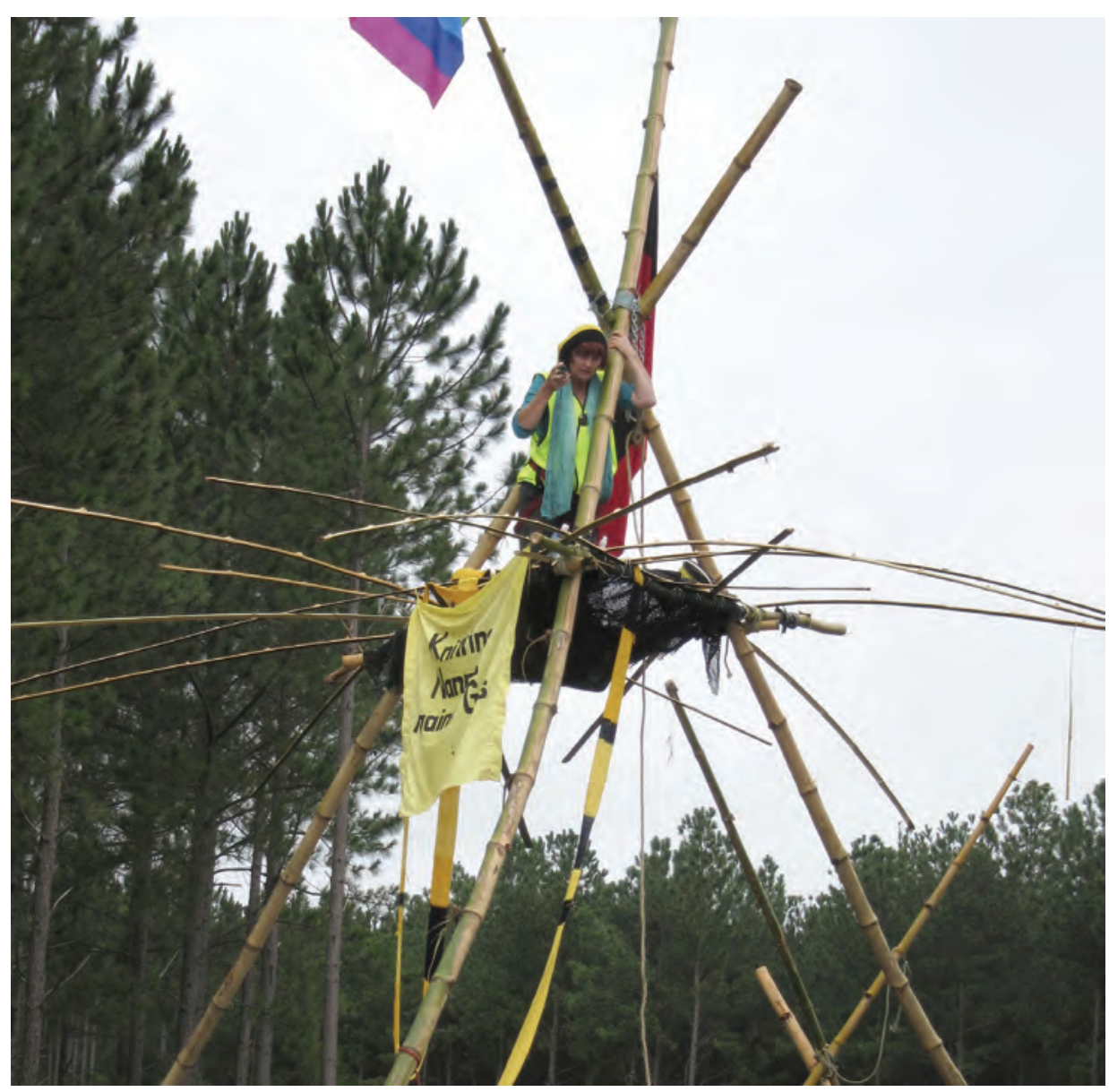

Figure 6. Clare Twomey filming blockade proceedings while locked-on to a tripod Photo: Liz Stops 2013

The KNAG soft barrier is a symbolic gesture and, as such, is connected to the works of contemporary artists who act to disempower war machines by covering objects used in warfare or duplicating them as a knitted object. Marianne Joergensen's Pink M.24 Chaffee was conceived as a protest against the involvement of Denmark, the United Kingdom and the United States in the war in Iraq (Joergensen). An ex-World War II tank was covered with pink knitted and crocheted squares made by volunteers from many European countries and the United States. For Joergensen, 'the tank is a symbol of stepping over other people's borders. When it is covered in pink it becomes completely unarmed and loses its authority' (Joergensen in Pentney 2008). Black and Burisch affirm that if 'the blanket is read as a petition, each panel ... acts as a stand-in for a signature, but instead of being delivered pleadingly to a government elite, this gesture defiantly occupies public space' (2010: 611). 
Barb Hunt's work, Antipersonnel, operated similarly by duplicating landmines in pink yarn, transforming a destructive object into one that can do no harm, to show that 'knitting functions as a metaphor for recuperation, protection and healing' (Hunt: 2005). Wrapping, in many contexts, can signify care, nurture and reassurance, from swaddling babies to enfolding fine china to binding mummies and even covering teapots (Gordon 2011: 26). KNAG members shared such aims when they were invited to attend ANZAC celebrations in April 2013 at Acland, Queensland, a small town with an original population of 400 that now, decimated by coal mining, is reduced to one lone resident. Invited by artist Nicki Laws and past residents to shine a light on the damage done to community by mining, Twomey's 28-metre knitted length was wrapped around entrance posts to the town common (Summers 2014). By framing the view to the common, attention was drawn to a place lost to use; a place that had been the scene of many fondly remembered community events, which is now deserted space.

The KNAG soft barrier in the form of an ever-lengthening symbol of empowerment and optimism also has similarities to Kris Lindskoog's I Want to do Something Kind for the Planet, and Germaine Koh's Knitwork. Lindskoog knotted a 61-metre friendship bracelet from embroidery thread and his aim was to eventually make this work long enough to circle the equator (Black 2006). Since 1992, Koh has been knitting a gigantic scarf, which will be complete when she dies (Koh 1992). Made from unravelled used garments it records the 'passage of time and effort ... is both sublime and resolutely absurd ... both rigorous and formless' (Koh 1992). Twomey's promise is to continue knitting her yellow and black length until UGM has been halted in Australia.

Hunt also suggests that there is 'a close association of knitting with caring for the body' (Hunt 2005). As a nurturing gesture some KNAG members have fashioned cushions for protestors, or 'protectors' as they prefer to be called, who may be uncomfortably immobilised for long periods of time when lockedon underneath large machinery. Many hours of immobilisation might be required as the police assemble personnel and equipment to cut through sections of machinery while maintaining safety. Although police may remove cushions, the gesture of placing them under and around the person who is immobilised can still offer physical and emotional support in taxing circumstances. In addition, knitted sleeves have been threaded onto lock-on chain to prevent blisters on the skin of the wearer. Considerate acts such as this 'refocus attention on the value of small personal gestures that can accumulate into a declaration of caring and hope' (Hunt 2005). In such instances, knitted items may be destined for destruction, but nonetheless, damaged work, if recovered, is labelled and displayed at subsequent events.

Yellow and black hats are the most ubiquitous of the functional knitted objects that are worn by KNAG and its supporters. 'Clothing can seem to hold the energy of a particular quality or status' (Gordon 2011: 31) and KNAG hats, as symbols of allegiance, are sold to raise funds and offered to people deemed deserving, such as those who actively engage in protests and blockades and to those politicians who have stated their opposition to UGM. 


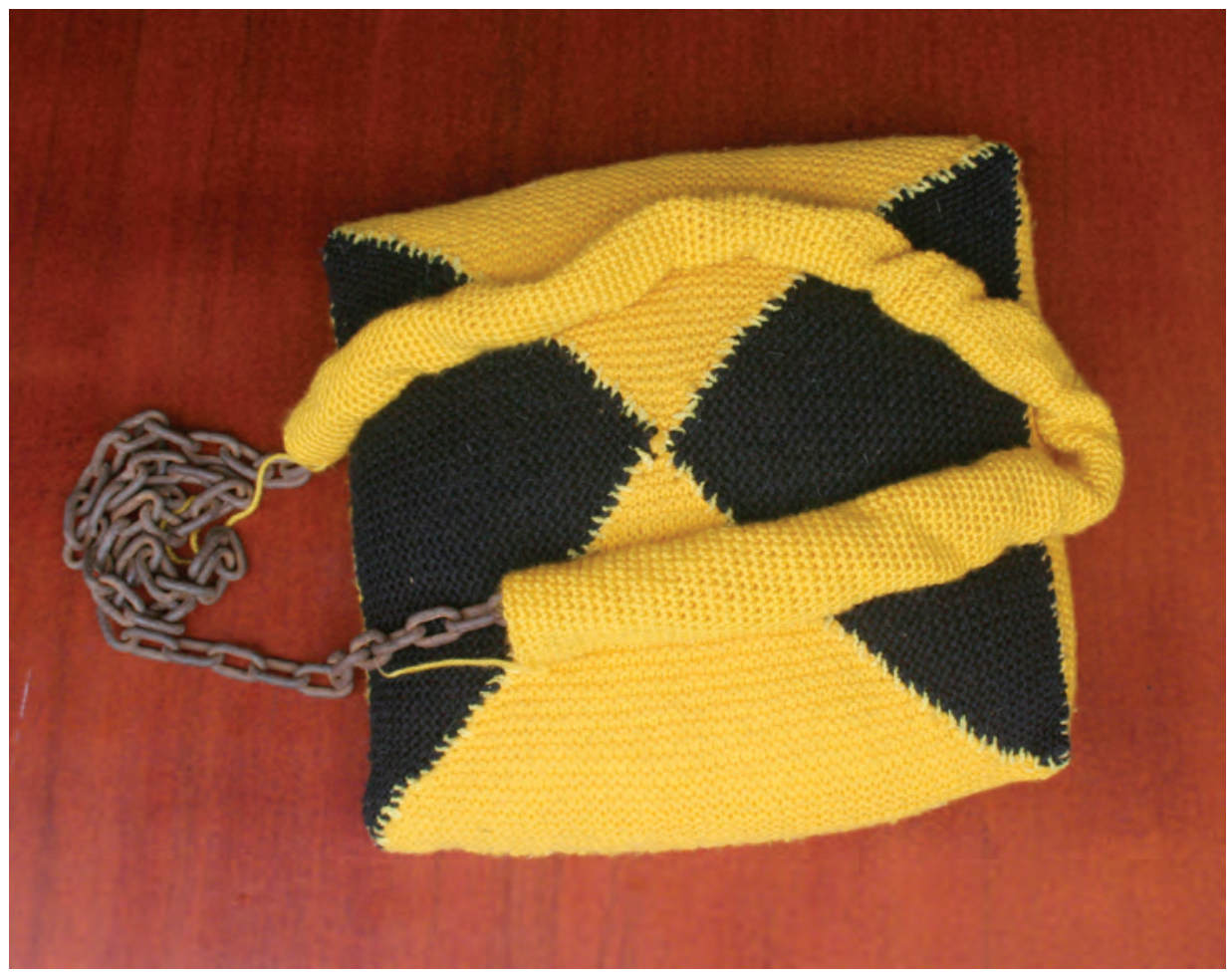

Figure 7. Cushion and chain sleeve; lock-on comfort provided by KNAG

Photo: Liz Stops 2013

In June 2013 at Parliament House in Canberra, the entrance to the building was temporarily blocked by anti-UGM activists, including a few Nannas, effectively closing down the main entrance to the nation's seat of power (Carroll 2013). As they arrived, politicians who had been vocal against UGM were offered a KNAG hat. Knowing the implications, and due to a strong media presence, some refused. Christine Milne, Leader of the Australian Greens, Larissa Waters, an Australian Greens Senator, and Bob Katter, leader of Katter's Australian Party, however, accepted the gift and, therefore, the association with KNAG and the subsequent publicity.

Triangles are knitted in many sizes, echoing the LTG Alliance versions, and are sometimes sewn together to fabricate larger structures resembling banners or flags. According to Gordon, '(o)ne of the reasons flags can be such potent symbols is that they move with the wind. When a nation is represented by a waving flag, that nation is symbolically alive and active; it is a dynamic presence' (2011: 33). 


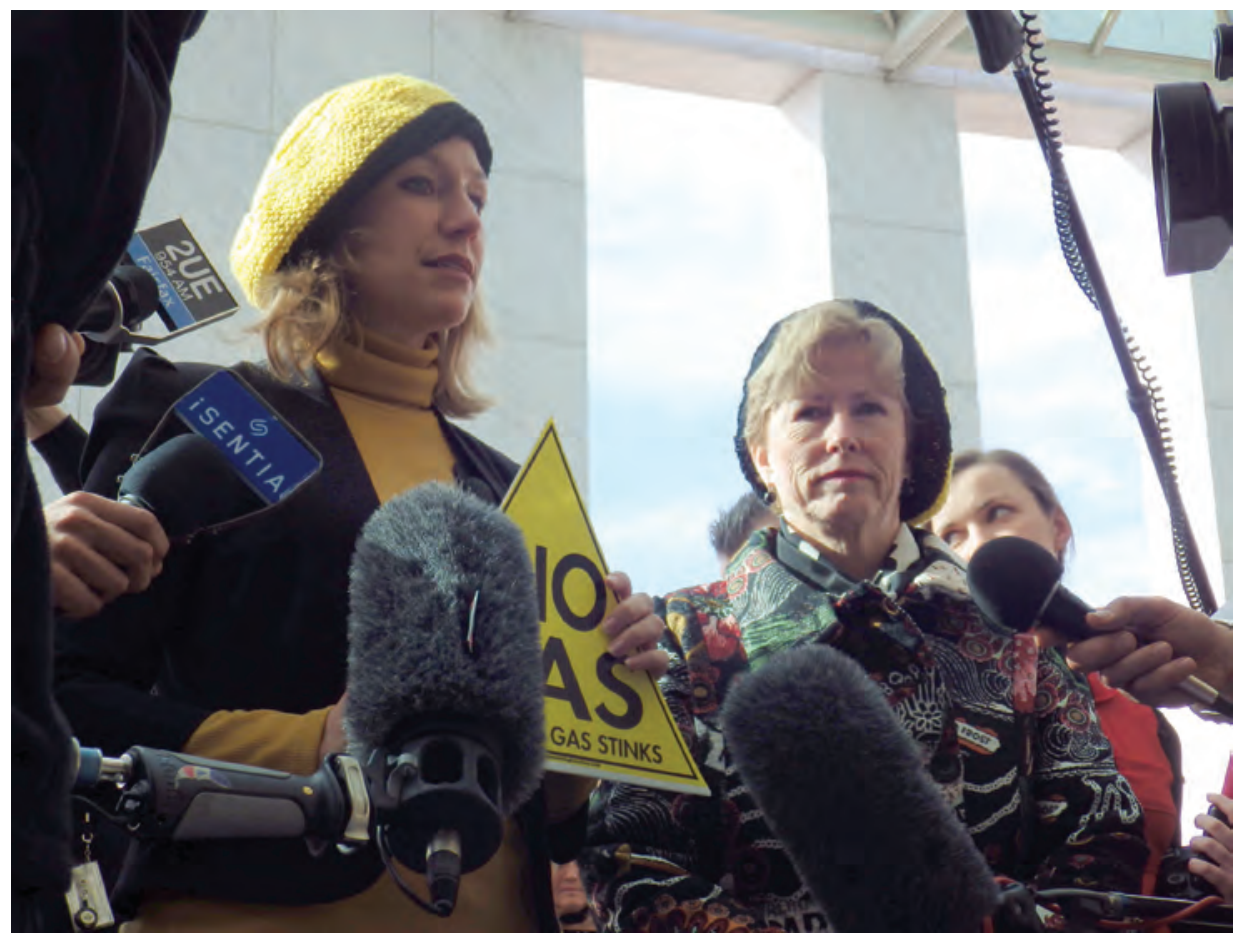

Figure 8. Christine Milne and Larissa Waters wearing KNAG hats

Photo: Jenny Leunig 2013

KNAG members also initiate and engage in social actions that promote care for community, such as hosting fundraising events for specific causes associated with the anti-UGM movement. In 2012 a group of Nannas travelled to the Tara and Chinchilla gasfields in Queensland and witnessed the degradation of land and divisions within community that have occurred due to massive industrialisation of the area in the development of CSG. They were struck by the poor health of residents, particularly children who lived not far from gas wells. Expensive medical tests were required, for which the affected families were personally liable. In order to help pay for the tests, Nanna Anne Thompson organised a concert she titled The frack off the rig gig in March 2013 for which local musicians performed voluntarily. Hosted by the Lismore Workers Club, it was well supported by the local community and raised many thousands of dollars, which formed part of a fund dedicated to the medical care of the Tara community. 


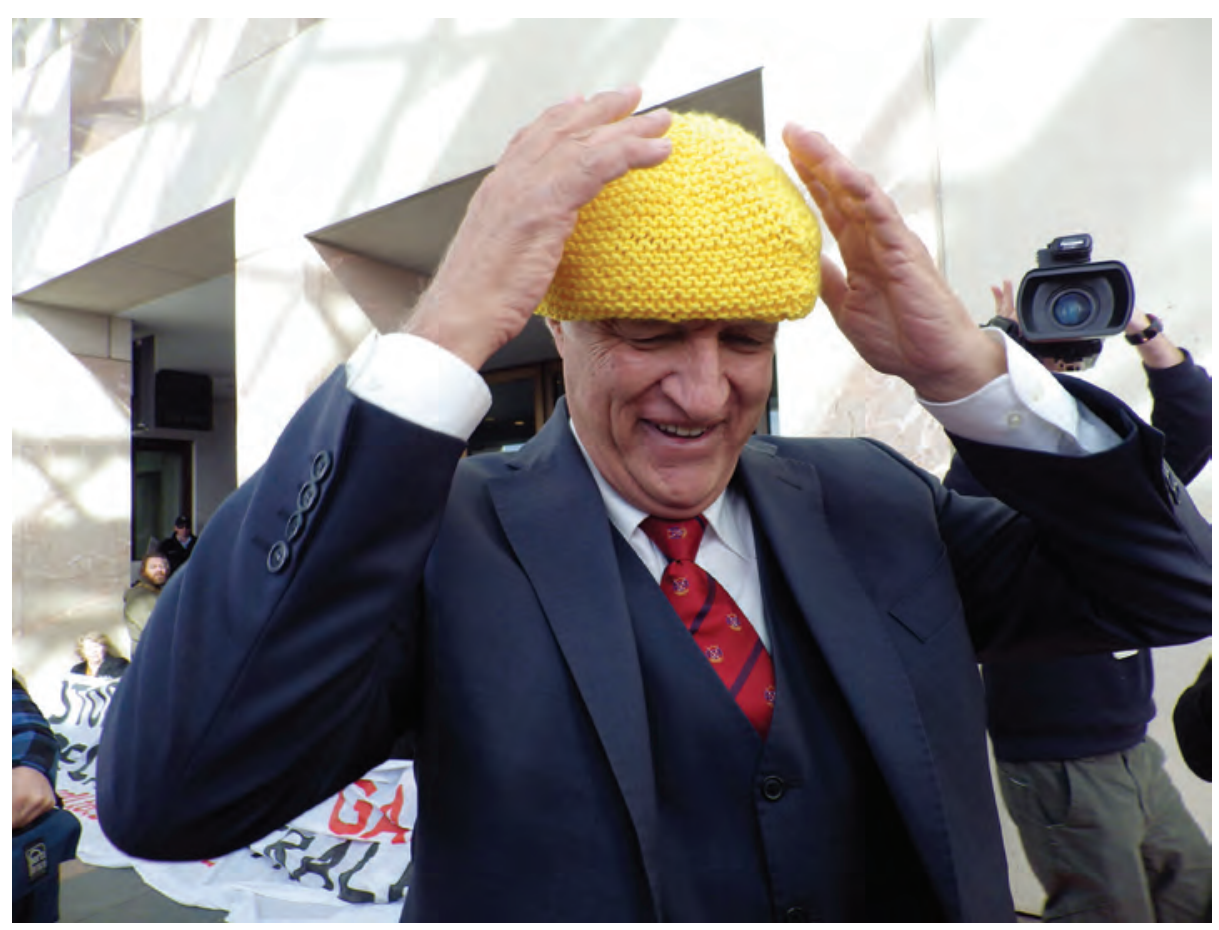

Figure 9. Bob Katter wearing a KNAG hat

Photo: Jenny Leunig 2013

In another instance, during the blockades at Glenugie and Doubtful Creek, many arrested protectors were potentially subject to heavy fines. Nanna Judi Summers organised a screening at a Lismore cinema of Promised Land, a movie depicting the infiltration of a rural community by a CSG company. Although fictional, the plot echoed some of the tactics that had been deployed locally, and that had resulted in divisions within community, and sometimes even within families. Money raised from this event helped pay arrestees' legal expenses.

A KNAG presence at blockades, rallies or meetings with politicians is highly valued by protectors. During blockades various roles are undertaken, including arrestee support. This includes briefing those who choose to place themselves in an arrestable situation as to what psychological and physical extremes they might experience. It also involves following the police vehicle in which the arrestee is transported to the police station and then assisting that person in whatever way is necessary, including ensuring that he or she has food or extra clothing and is taken home when released from custody. 


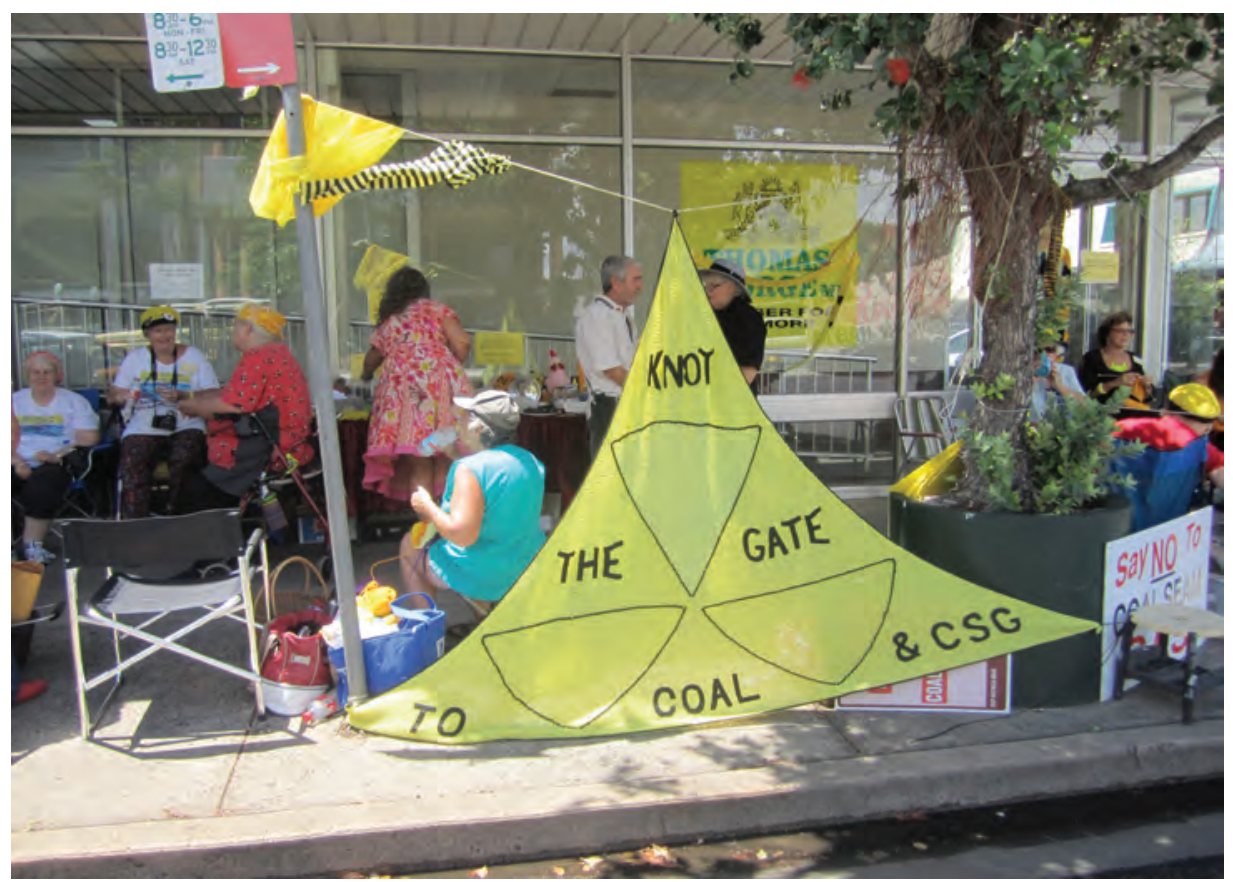

Figure 10. KNAG banner

Photo: Clare Twomey 2013

Knitting is conducted by a group in the midst, sometimes, of mayhem, as police attempt to break the ranks of protectors. Dean Draper, a key player in the Doubtful Creek blockade observed that the presence of knitters has a calming effect on protectors, UGM workers and police alike (Draper 2013). A cluster of women knitting in the midst of potentially volatile circumstances has the power to defuse aggression and even generate humour. Who could resist smiling at Nanna Jenny Leunig, knitting in hand, her T-shirt printed with 'NO CSG' on the front and 'HANDLE WITH CARE, NEW HIP REPLACEMENT' on the back as she warned the policeman in charge of breaking the Doubtful Creek blockade of her medical condition. He organised a safe place for her to participate, ensuring she could bear witness away from the melee. Leunig's diversion, although legitimate, helped de-escalate and disrupt the inherent violence associated with a large contingent of police intent on breaking a several-hundred-strong blockade. 


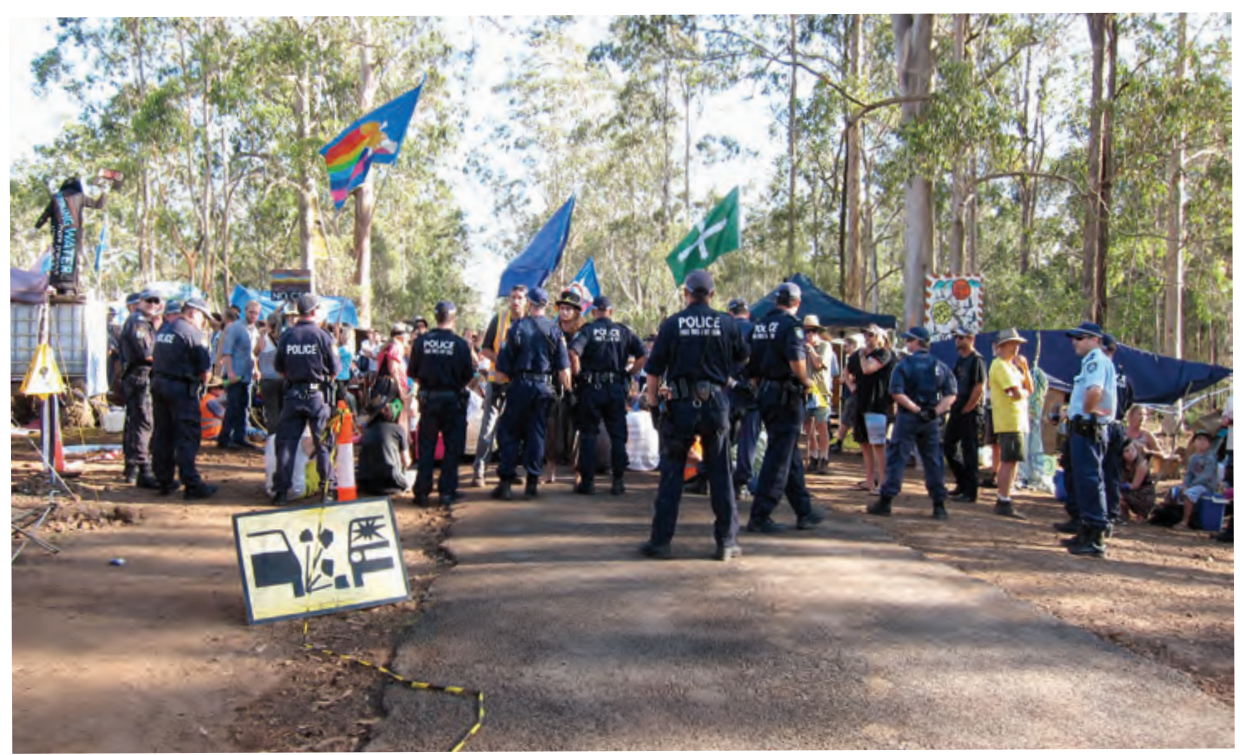

Figure 11. View of Glenugie blockade

Photo: Liz Stops 2013

Pentney discusses the importance of challenging 'truth-claims and taken-forgranted certainties that often marginalise and silence groups of people' (2008). The presence of an orderly group of knitters is a direct contradiction of the 'extremist' or 'lunatic fringe' label touted by politicians and mining executives (Hinman 2013). Black expresses this contradiction as 'the simultaneous unruliness and gentleness of public knitting ... when a large roaming group of knitters occupies a public place or place of power with a non-violent action ... that creates a constructive dialogue' (2006: 611). In this instance, KNAG operates in a similar way to the RKC who, Robertson notes, used 'knitting and crocheting as ways of highlighting the media exaggeration of violence among protestors, of creating community-based, collaborative and grassroots actions, of crossing lines of age and gender ...' (Robertson n.d.). 


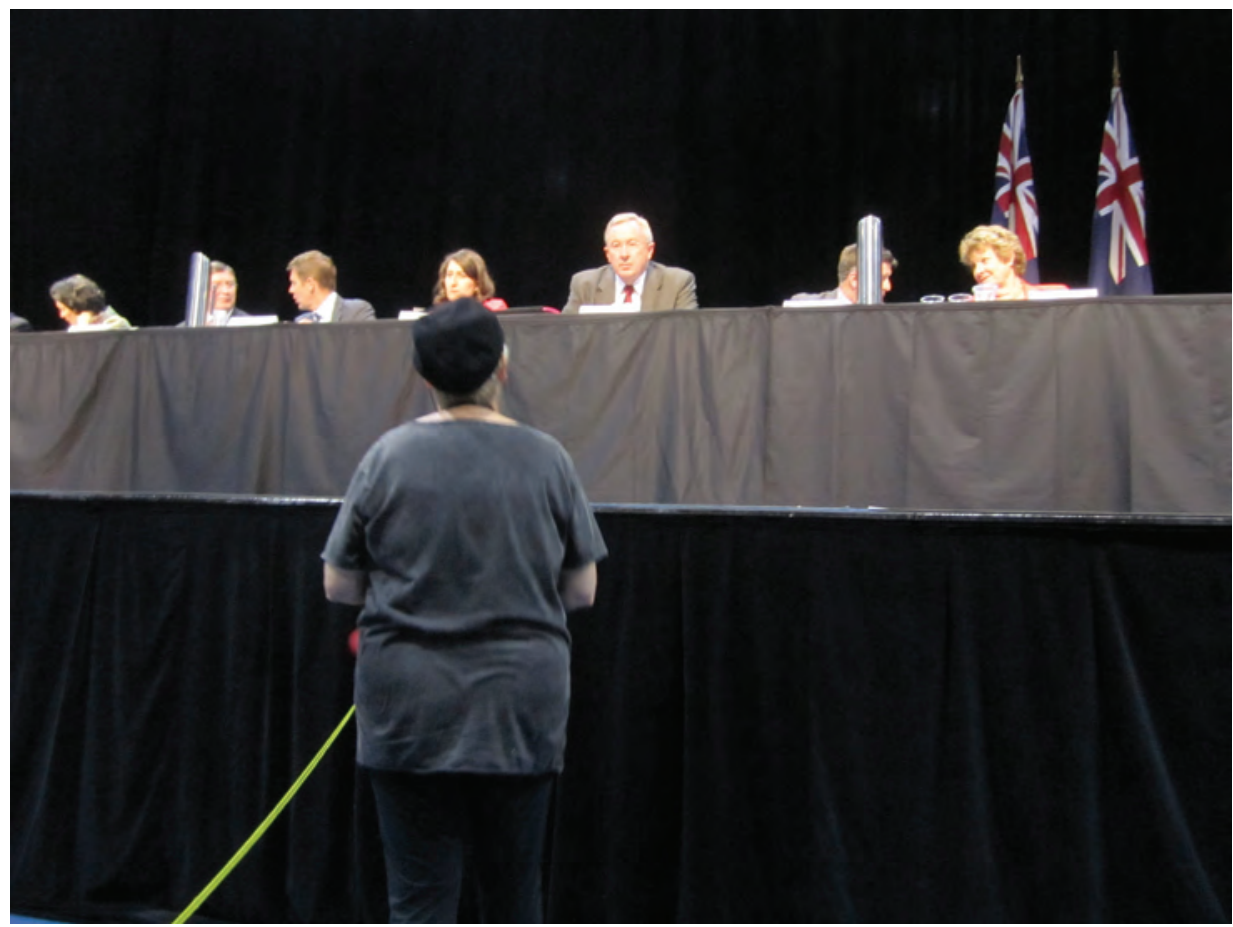

Figure 12. Jenny Leunig questioning NSW Minister for Planning Brad Hazzard at a Tamworth parliamentary sitting, November 2012

Photo: Clare Twomey 2012

Knitting quietly does not indicate timidity, but it does indicate persistence. Leunig's determination to be heard exemplifies KNAG principles. She, Twomey and Louise Somerville drove six hours from Lismore to Tamworth for the last state parliament sitting for the year in November 2012 in order to have their questions on UGM answered by the premier of New South Wales, the minister for planning and the minister for resources and energy. Figure 11 shows Leunig, having being passed over at question time, walking forward trailing her knitting, insisting on a response to her question.

Another similarity between KNAG and the RKC is the choice to knit on the 'doorsteps of corporate headquarters' (Robertson n.d.). To this end, purposeful witness bearing also takes place regularly on road frontage outside Metgasco's Casino office. KNAG members, with banners flying, sit knitting on the road verge for two hours at a time. The intention is to put the company on notice and remind the CEO that, although the CSG mining enterprise has gained approval from the NSW state government, no social license has been given. 


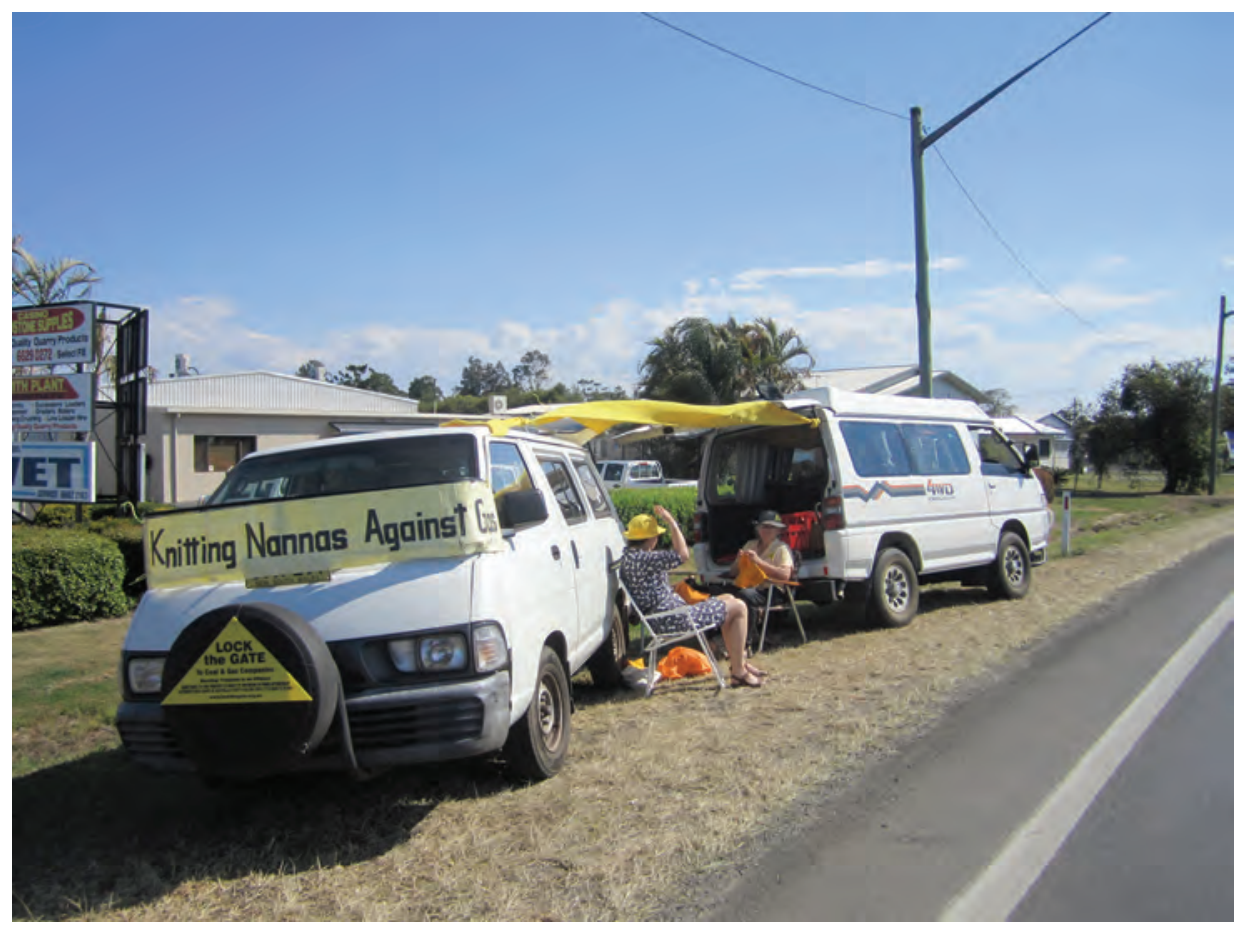

Figure 13. Knitting on the road verge outside the Metgasco office, Casino Photo: Clare Twomey 2012

Another form of bearing witness, this time at political headquarters, is the gathering and knitting that has taken place every Thursday since June 2012 outside the Lismore office of the local state member, to reaffirm to him that he should properly represent his constituents. Lismore council commissioned a survey in conjunction with council elections in September 2012 and 87 per cent of the local population voted against CSG mining (Harlum 2012). 


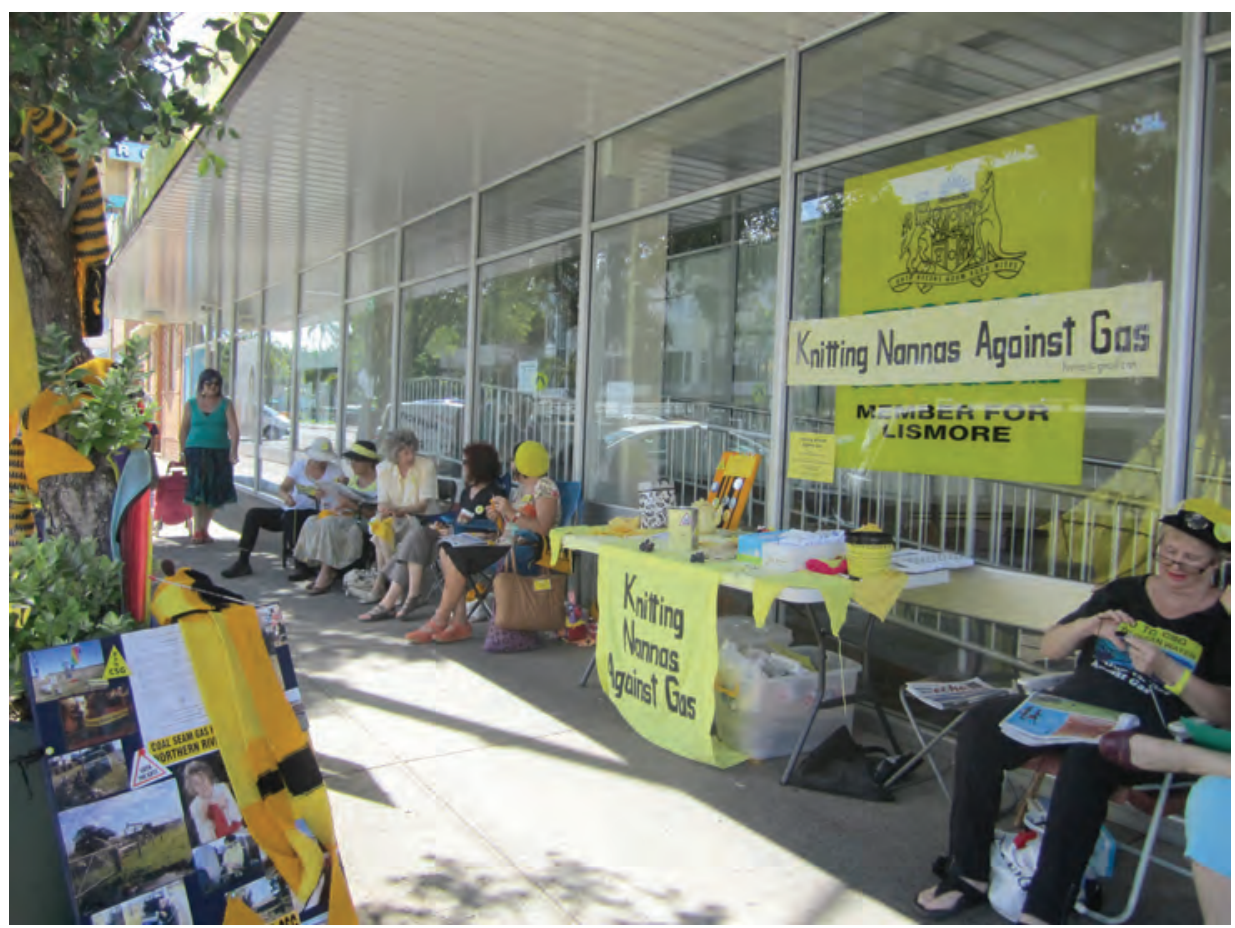

Figure 14. Nannas outside Thomas George's office

Photo: Clare Twomey 2013

The opportunity for community engagement at that site has been maximised by distributing information to, and engaging in discussion with, passers by. According to Black and Burisch, the 'interactions and discussions that take place during group knitting also act as an accessible forum for teaching, sharing, and promoting activist strategies and politics' (2010: 611).

Just as the warp and weft of weaving can be viewed as a metaphor for social interaction (Creighton 1994: 111), so too can the plain and purl of knitting. Facebook has been a useful and consistent connection with a local, national and international audience and its use has resulted in widespread popularity and increasing awareness. The threads of social connection made possible through Facebook can be seen as metaphorical of stages of the knitting process, of casting on, dropping stitches and of building patterns. Between 13,000 and 30,000 people visit the site each week. Access to social media and the platform for supportive communication that it provides has encouraged KNAG groups to form in different locations. Enthusiastic knitters from several other states and countries have been keen to adopt the Nannafesto and emulate KNAG methods of non-violent but determined confrontation. They are not all fighting against UGM, but have all adopted knitting as a basis for their activities. For instance, a KNAG branch is attempting to protect old growth forests from logging in the Toolangi State Forest in Victoria (Twomey 2013): the forest is the habitat of the 
endangered Leadbeater's possum. Protectors there have been issued with an injunction to remain 150 metres from log trucks. As a consequence, a knitted work of the same length has been constructed to measure out that distance at each confrontation and KNAG in Lismore has contributed a ten-metre length to the project.

KNAG believe that it is important to maximise any opportunity for publicity and local media are encouraged to attend and document events. KNAG activities have been consistently reported in local newspapers the Northern Star and the Lismore Echo. KNAG featured in Risky Business, a documentary made by Aljazeera about CSG mining in Australia that screened locally on Fox TV in January 2013. In January 2014 Rani Brown's documentary Knitting Nannas won highly commended in the Flickerfest GreenFlicks Award for the Best Environmental Short Film (Flickerfest 2014). KNAG members were also declared Climate Heroes for 2014 by the Australian Youth Climate Coalition (AYCC).

\section{Conclusion}

The craft of knitting with its many associations in Western cultural memory of care, calm, nurture and diligence underlies all KNAG projects and KNAG is firmly embedded in historical and contemporary craft activism. Although craft may be perceived by some as old fashioned or irrelevant, I have shown here that it can also function as a powerful strategy to examine and challenge contemporary issues and materially, socially and ideologically contribute to the crafting of culture.

By engaging with the knitting strategies of KNAG, people from diverse professions and different political persuasions have been able to collectively develop a sense of empowerment. No longer helpless in the face of corporate might or political disregard, knitting has provided a language with which to speak.

Dr Liz Stops works in a variety of media, devising representations of landscape that respond to and interpret her research into historical British colonial occupation of Australia and current corporate colonisation, with an emphasis on environmental implications. Liz tutors in the 3D studio of the Visual Arts Department at Southern Cross University.

\section{References}

Australian Youth Climate Coalition. 2014. '2014 Climate Hero Awards', viewed 23 February 2014, http://aycc.org.au/climateheroes.

Black, A. 2006, 'Super string', Stride, viewed 18 March 2013, http://www.stride. ab.ca/arc/archive_2006/super_string_main/super_string.htm. 
Black, A. \& Burisch, N. 2010, 'Craft hard, die free: Radical curatorial strategies for craftivism in unruly contexts', The Craft Reader, New York: Berg.

Carroll, A. 2013, 'Knitting nannas lock Parliament House in CSG protest', Northern Star (Lismore), 21 June.

Creighton, M.R. 1994, 'Nostalgia, identity and gender: Woven in 100 per cent pure silk', in G. A. Hickey (ed), Making and Metaphor: A Discussion of Meaning in Contemporary Craft, Quebec: Canadian Museum of Civilisation, pp. 100-113.

Darian-Smith, K. \& Hamilton, P. 1994, 'Introduction', K. Darian-Smith \& P. Hamilton (eds), Memory and History in Twentieth Century Australia, Melbourne: Oxford University Press, pp. 1-6.

Davis, D. 1979, Yearning for Yesterday: A Sociology of Nostalgia, New York: Free Press.

Draper, D. 2013, conversation with the author.

Flickerfest 2014, Flickerfest 2014 - Awards, viewed 17 February 2014, http:// flickerfest.com.au/press-releases/2014-awards/.

Fork Films 2008, Pray the Devil Back to Hell, viewed 22 February 2014, http:// praythedevilbacktohell.com/synopsis.php.

Galloway, A. 2006, 'Knitting and public politics', purse lip square jaw, viewed 22 February 2014, http://www.purselipsquarejaw.org/2006/08/knitting-andpublic-politics.php.

Gbowee, L. \& Mithers, C. 2013, Mighty Be Our Powers, Beast Books.

Gordon, B. 2011, Textiles: The Whole Story: Uses, Meanings, Significance, London: Thames and Hudson.

Hamilton, P. 1994, 'The knife edge: Debates about memory and history', in K. Darian-Smith \& P. Hamilton (eds), Memory and History in Twentieth Century Australia, Melbourne: Oxford University Press, pp. 9-32.

Harlum, S. 2012, 'Stoner Feels Fury', Northern Star (Lismore), 30 June.

- - 2012, 'Thumbs down to CSG industry', Northern Star (Lismore) 11 September.

Hinman, P. 2013, 'Pro-gas pundits label activists "extremist fringe"', Green Left Weekly, 1 June.

Hunt, B. 2005, 'Antipersonnel', barb hunt, viewed 17 April 2013, http://www. barbhunt.com. 
Joergensen, M. Pink M.24 Chaffee: A Tank Wrapped in Pink, viewed 20 May 2013, http://www.marianneart.dk.

Knitting Nannas Against Gas 2014, 'Nannafesto / Knit the dream', viewed 23 February 2014, http://www.knitting-nannas.com/philosphy.php.

Koh, G. 1992, 'Knitwork', Germaine Koh, viewed 30 May 2013, http://www. germainekoh.com/ma/projects_detail.cfm?pg=projects\&projectID=87.

McCalman, I. 2006, 'Teddy Roosevelt's trophy: History and nostalgia', in M. Lake (ed), Memory, Monuments and Museums, Melbourne University Press, pp. 58-75.

Pajaczkowska, C. 2005, 'On stuff and nonsense: The complexity of cloth', Textile, vol. 3, no. 3, pp. 220-48.

Parker, R. 1996, The Subversive Stitch: Embroidery and the Making of the Feminine, London: The Women's Press Ltd.

Pentney, B.A. 2008, 'Feminism, activism and knitting: Are the fibre arts a viable mode for feminist political action?', Thirdspace: A Journal of Feminist Theory and Culture, vol. 8, no. 1, viewed 3 April 2013 http://journals.sfu.ca/ thirdspace/index.php/journal/article/viewArticle/pentney/210.

Pocius, G.L. 1994, 'Craft and cultural meaning', in G.A. Hickey (ed.), Making and Metaphor: A Discussion of Meaning in Contemporary Craft, Quebec: Canadian Museum of Civilisation, pp. 125-131.

Robertson, K. 'The viral knitting project: An ongoing collaboration', Kirsty Robertson, viewed 22 June 2013, http://www.kirstyrobertson.com/viral\%20 knitting/viral\%20knitting.html.

Stephens, H.M. 1891, A History of the French Revolution, vol. 2, London: Longmans, Green and Co.

Summers, J. 2014, conversation with the author, 22 February.

Twomey, C. 2013, conversation with the author, 23 March. 
This text taken from craft + design enquiry issue 6, 2014, Craft.Material. Memory, Edited by Anne Brennan and Patsy Hely, published 2014 by ANU Press, The Australian National University,

Canberra, Australia. 